\title{
The Muslim-Ethical Norms Combat against Corruption; Are Islamic Perspective been Met in Practice?
}

\author{
Aina-Obe Shamsuddin Bolatito \\ (PhD Candidate), Department of Public Administration, School of Business Studies, Sudan University of Science and technology, \\ Khartoum
}

\begin{abstract}
The principal objective of this paper is to research the Islamic position on corruption and to employ a variety of terminology and narration to elucidate and condemn a broad category of behavioral digressions involving corruption including bribery and nepotism. Corruption is seen to stem from the abuse of administrative power of any kind, judicial power, political authority and financial dominance. Further, all corrupt acts are construed as lacking in virtue from religious and moral perspective and unjust in relation to the principles that safeguard rendering to everyone their due, thereby undermining communal harmony. Accordingly, this paper will analyze the Islamic perspective on corruption, in particular bribery as a common form of corruption in the religio-society. As all heavenly religions condemns corruption as a severe threat to proper social, economic, and ecological balance. Corruptions in Islam are taboo in Sharia law because they are considered grave criminal offenses and a great sin. However, Muslim nations have been deficient in addressing the issue in their national laws and have failed to meet the lofty standards of Islam. As this paper will uncover, the needs to combatcorruption has brought all state holders much closer together by setting up various anti-corruption agencies. It recommends developing a firm belief in transcendent accountability and stresses character building through practicing moral virtues and shunning vices.
\end{abstract}

Keywords: Islam, Corruption, Sunnah, Quran, Wealth, Muslim, Punishment, development.

\section{Introduction}

The way in which corruption has been defined in recent years moved the discursive arena away from corruption as a social pandemic that needs an urgent attention of religious, ethical and norms of personal believes or faiths. This is because various anti-corruption agencies and human rights bodies are yet to find a lasting antidote to this socioeconomic pandemic. The World Bank defines corruption as the abuse of public office for private gain" (World Bank, 1997,).

Ethics are loosely implied in this definition of corruption but are certainly not made explicit. Discourse analysis of the World Bank's literature on corruption has revealed a process that established a particular definition that limits the study of corruption to public office holders and economics (Marquette, 2003; Polzer, 2001). This was done to meet the needs of a particular organization but not indicating faiths based institutions doctrines.

The lacking of faiths based doctrines on corruption has impacted the study of corruption as a whole in a narrow minded syndrome. As Bukovansky points out, Đespite its moral overtones, the bulk of contemporary anti-corruption discourse deploys the language and methodologies of economics and rational choice to render diagnostic assessments of the plight of the corrupt and less developed" (Bukovansky,2006).According to Wraith and Simpkins, -Crruption is above all a moral problem, immeasurable and imponderable" (Wraith and Simpkins, 1963). Moral definitions of corruption have been centered on Eurocentric, Americanism and are delved of Africanize definitions and religious doctrines. Recently, President Goodluck Jonathan of Nigeria said There is no corruption but mere stealing in
Nigeria" adding another definition to the term -Crruption" from the Nigerians understanding.

This is why, decades into the contemporary study of corruption, academicians continue to be faced with dilemmas of definitions. In an effort to strip the debate of any of its moral complexity, it has been rendered problematical at best, nonsensical at worst (Marquette, 2007).Benjamin and Nkechinyere 2014 argued that Corruption in Nigeria is a product of capitalism. In other words, capitalism is the mother of corruption in Nigeria and Africa in general, while materialism is her elder sibling". When Karl Marx predicted that capitalism will sow the seeds of its own destruction, he meant that capitalist societies will create the necessary conditions that will give rise to revolutions (www.sociology.org.uk). Such conditions include corruption, exploitation, massunemployment and dehumanization of the working class by the owners of the capital, thereby giving rise to frustration and depression (Giddens, 1981).Definitively, capitalism is a system where an individual can own and control a lot of wealth and use it to create more wealth for himself (Giddens, 1981). It is in sharp contrast with communalism which is the African traditional socio-economic system whereby Africans were their brothers' keepers in matters of economic production and possession. With the advent of capitalism with its associated individualism and private ownership of capital, African communalism with its characteristic extended family system gave way to individualistic struggle for private wealth production (Chukwuezi, 2000). This was the condition that gave rise to corruption in Africa, otherwise corruption was not known during the communalist era, therefore, religious holistic approaches needs to comes in to combat this pandemic. 


\section{International Journal of Science and Research (IJSR) \\ ISSN (Online): 2319-7064}

Index Copernicus Value (2013): 6.14 | Impact Factor (2015): 6.391

This paper argues for applying religious doctrines and a unified ethical theory in the fight against the pandemic corruption. Its first defines corruption from the perspectives of Muslim Scholars, an Islamic faith understanding by noting that Islamic doctrines can envision a lasting solution and provide the centuries missing antidotes to the pandemic corruption if Islamic doctrines and other heavenly reveled faiths are given chances and applied. Its goes further to explain the roles of ethical norms as a universal alternative antidote as core values do exist across cultures. In the final section, its recommends how we can improve ethics in organizations.

\section{Objectives of the Study}

1) To study the Islamic guidelines in abolition and eradication of corruptions and fraudulent practices our societies.

2) To identify the impact of corruption on socio-economic transaction of any country.

3) To identify why Muslim dominated countries are finding it uneasy to eradicate corruptions in their societies.

4) To achieve the efficient uses and management of resources and fund as prerequisite for a balanced societies free from poverty and human wants.

5) To have our societies conduct themselves in accordance with the highest levels of integrity expected as men and women of Islamic religious understanding.

\section{Theoretical Discussion}

Corruption is a threat to ethical values and justice and hampering sustainable development and the rule of law. Corruption reduces investments, socio-economic growthand infrastructural development of any country. Developments which are hampered by distorting the rule of law and weakening institutional foundation which is the base of economic growth. The poor are the victim of corruption. They are more reliant services and are not capable to pay extra cost associated with bribery, fraud etc. Justice is also undermined in many parts of the world by denying victims and the accused the basic human right to fair and impartial trial. Corruption impedes collective decision making and people's power to influence collective decision making through speaking and voting. Corruption brings injustice, inefficiency, mistrust of the Government by the citizen, waste of public resources, discouragement of enterprises, institutions, and restriction on Government policies (Md. Shahnur and Md Musa, 2013).

In the Qur'an and Sunnah, corruption refers to a broad range of behavioral digressions that threaten the social, economic, and ecological balance. Such acts are clarified at various places in the Qur'an in plain language, in terms of being just or unjust, with reference to their detrimental impact on social organization, and within relation to the standards of moral virtue.

\section{The Categorization of Corruption and Bribery in Islamic Law}

A. Islam unlike other religions, dictates all behavior undertaken by Muslims as sunnah (practices and approval of Prophet Muhammad, saw) including commercial relations Islam stresses the importance of the spiritual factor in every realm of human activity, including the economic one, to ensure it is in harmony with the goals and values of Islam. The term Islamic Law" is generally used in reference to the entire system of law and jurisprudence associated with the religion of Islam, including the primary sources of law and the subordinate sources of law, as well as the methodology used to deduce and apply the law (John L. Esposito ed., 1995). Islamic law is divided into worship (Ibadat) rules governing the relationship between an individual and God (-Alah") and transaction (Mo 'amalat) rules governing the relationship between individuals and societal norms, which are changeable and develop according to time and place.

Muslim jurists differ in defining corruption. Literally, corruption (Fasad) encompasses mischief, abuse, rottenness, spoiledness, decay, decomposition, putrefaction, depravity, wickedness, viciousness, iniquity, dishonesty, and pervertedness (HANS WEHR, 1976). There are numerous definitions among Muslim jurists. Some scholars state that bribery (Rashwa) is the principle form of corruption and define it as what is given to invalidate a right ( Haq) or to validate a deception or falsehood (Batil). Others say that bribery is a gift, whether in real or monetary terms, presented to judges and other decision makers to facilitate a favorable ruling or judgment. Other jurists say bribery is an abuse of judicial oradministrative power or of political authority, trust, or financial prowess.

From these concepts, we can say that most Muslim jurists see bribery as epitomizing corruption as —-smething given by the briber and received by the bribed irrespective it is a material or a moral thing, money or a benefit. Thus, having canvassed Muslim scholars, we can describe corruption as -evering the matters of governance, decision making, rules through reproaching the abuse of trust placed in officials by the state through acts such as accepting gifts, outright theft of public funds, and undermining rules in exchange for bribes, on recommendation or due to family and tribal considerations. Finally, individuals in general are prohibited from making recommendations in exchange for gifts as such behavior falls under rashwa.

\section{B. Other Concepts Categorized as Bribery in Islam}

Various concepts are in close connection with bribery, including illegal earnings, gifts, charity, and salaries.

(1) Al-Soht (Illegal Earnings) - its means prohibited earnings and the maximization of profits in an illegitimate manner bribery given to the witness to testify, the judge to rule, and the price of power." It is the kind of corrupt behavior explained by the following Qur'anic verse:-They are fond of listening to falsehood, of devouring anything forbidden“". (Al-M_i'idaha, V 42).

(2) Al-Hadiya (-Gifts")- Al-Hadiya means to give something without any compensation in a real or a monetary form. 185 It is supported by this Qur'anic verse: 


\section{International Journal of Science and Research (IJSR) \\ ISSN (Online): 2319-7064}

Index Copernicus Value (2013): 6.14 | Impact Factor (2015): 6.391

To Allah belongs the dominion of the heavens and the earth. He creates what $\mathrm{He}$ wills and plans. He bestows children male or female according to His Will and Plan, Or He bestows both males and females, and He leaves barren whom He will: for He is full of Knowledge and Power' (AlShoura V49-50).

Thus, the goal of both a gift and a bribe is to transfer the benefit to the other, although with a gift there is no compensation expected. In contrast, the briber anticipates his private benefit from the bribe.

(3) Al-Sadaqah (-Eharity")

Al-Sadaqah means giving charity to poor people in order to be blessed and receive the mercy of God, which is the only true purpose of giving Sadaqah.190 This Qur'anic verse explains charity: If ye disclose acts of charity, even so it is well, but if ye conceal them, and make them reach those really in need, that is best for you: It will remove from you some of your stains of evil. And Allah is well acquainted with what ye do. Accordingly, charity involves giving without any monetary or nonmonetary compensation. On the other hand, sometimes the bribe is a poor person or the briber gives whatever he wants to give in order to be closer to him, but in reality he has a private interest. In such an event, charity becomes disguised bribery.

\section{(4) Al-Ga_al (-Salary")}

Al-Ga_al literally means a wage. From the Islamic point of view, salary is a known monetary obligation upon a certain work, whether known or unknown. Although Ga_ala was originally permitted, some doctrines-namely the Hanafi and Shafi_ Islamic school of though-prohibit it in certain occasions where it might disguise fraudulent transactions. For instance, Goumhour Al- Fouqaha'a (-rajor scholars”) prohibit Ga_ala for judges or if it represents an obstacle to the realization of other legitimate public interests. Obviously, the reason for such prohibition is that, upon receiving the bribe, the bribee may represent it as his wage for the achievement of the briber's permissible private benefit. (Philip Khuri Hitti trans., 1968).

It is relevant here that the Prophet (PBUH) declined many who sought public appointments on the grounds that such positions are a trust and given only to those possessing appropriate merit. In disapproving one request he said Authority is a trust, and on the Day of Judgment it is a cause of humiliation and repentance except for one who fulfills its obligations and properly discharges the duties attendant thereon.

The second Caliph (Leader), Ummar Ibn Al-Khattab (RA), used to record the possessions of his officials at the times of their appointments and confiscated wholly or partly whatsoever they added while in office on suspicion of benefiting from their offices. Also, the Caliphinstructed one of his commanders to adjust the values of gifts offered to him-which he had dispatched to the central treasuryagainst the tax liability of the people, because taking anything more than the stipulated Jizya(h) (-poll tax") would have been unjust.

Caliph Ummar Ibn Abd Al-_Aziz (RA) said that: I am of the view that the ruler should not trade. It is also not lawful for the officer to trade in the area of his office... because when he involves himself in trade he inadvertently misuses his office in his interest and to the detriment of others, even if hedoes not like to do so. These examples suggest that corruption is understood in Islam as an abuse of trust through the misuse of judicial powers, administrative powers, riches, and political authority. (JUAN EDUARDO CAMPO, ENCYCLOPEDIA OF ISLAM 685 (2009).

\section{Rules Regarding Corruption and Bribery in Islamic Criminal Law}

The majority of Muslim scholars are in favor of the prohibition of corruption in all its shapes including nepotism, extortion, and bribery and they deduce this rule from various Islamic law sources such as the Qur'an, Sunnah, and Ijm 'a.( MOHAMED A. ARAFA, 2013)

\section{The Prohibition of Bribery in the Qur'an}

The Qur'an expresses the prohibition of corruption, including bribery, to further the prosperity of the people. Many verses emphasize and confirm this principle. Surat Al-Baqarah V188 reads, And do not eat up your property among yourselves for vanities, nor use it as bait for the judges, with intent that ye may eat up wrongfully and knowingly a little of other people's property."

This verse forces an injunction against illegal acts because it prohibits rulers, judges, decision makers, and parties to a conflict from facilitating the unjustified appropriation of the property of others or of public property by obtaining a favorable ruling in exchange for bribes. It calls such behavior Batil" (falsehood or deception) and Ithm" (criminal, sinful, inappropriate).

Correspondingly, Surat (Chapter) Al-M_i'idaha verse 42 states: They are fond of listening to falsehood, of devouring anything forbidden." This verse refers to certain Jews who had committed the forbidden act of Haram and eating property" through bribery. On another occasion, someone asked the Prophet Muhammad (PBUH), What is the AlSoht? He (PBUH) said: It is bribery. ( MOHAMED A. ARAFA, 2013)

\section{The Prohibition of Bribery in the Sunnah}

Muslims put considerable weight on events that took place in the early years of Islam, during the life of the Prophet (PBUH) and the early Caliphs. These years provide illustrations of appropriate behavior. In this respect, the Sunnah embodies the application of the Qur'an to both concrete disputes and hypothetical questions that arose during the Prophet's life. The importance of the Sunnah stems from the relationship between it and the Qur'an. The Sunnah may explain the rules and principles in the Qur'an, and it may present new principles and rules to supplement the Qur'an. exchange for bribes. It calls such behavior Batil" (falsehood or deception) and Ithm" (criminal, sinful, inappropriate). ( MOHAMED A. ARAFA, 2013)

3. Quranic verses and Hadith against bribery and corruption:

These are some verses of Quran which forbids us to indulge in bribery and corruption and inspires us to give the orphans 


\section{International Journal of Science and Research (IJSR) \\ ISSN (Online): 2319-7064}

Index Copernicus Value (2013): 6.14 | Impact Factor (2015): 6.391

and poor. By giving bribery we are unjust to the person who is harmed by it and also to the community and nation.

-Ad do not consume one another's wealth unjustly or send it [in bribery] to rulers in order that [They might aid] you [to] consume a partition of wealth of people in sin, while you know [it is unlawful]" (Quran 2, verse 188) 'Verily! Allah commands that you should render back the trusts to those, to whom they are due; and that when you judge between men, you judge with justice. Verily, how excellent is the teaching which he (Allah) gives you! Truly Allah is Ever All-Hearer, All -Heaver, All-Seer.'(Quran 4, Verse 58 , $-\Theta$ you who believed, be persistently standing firm of Allah, witness in justice, and do not let the hatred of a people prevent you from being just. Be just; that is nearer to righteousness. And fear Allah; indeed, Allah is acquitted with what you do" (Quran 5, verse 8,)

Indeed, those who devour the property of orphans and unjustly are only consuming into their bellies fire. And they will be burned in a blaze" (Quran 4, Verse 10,)

And the heaven He raised and imposed the balance, that you not transgress within the balance, and establish wealth in justice and do not make deficient the (due) balance. (Quran 55, verse 7 to 10, ) We made them (Abrahams and his son) imams who guided in accordance with our commandments, and we thought them how to work righteousness, and how to observe the charity (Zakat).To us they were devoted worship. (Quran 21:73,). The one who takes bribe and the one who gives it will both be in hell.

\section{The Sharie_A Attack on Corruption}

In order to eradicate corruption as an epidemic, Islamic law adopts various strategies on both local and global levels. All Muslim scholars, classical and modern, seek ways to tackle corruption. One of these strategies takes the form of Ta azir penal sanctions regarding bribery, discussed above. More broadly, the vast Islamic intellectual heritage suggests that education, law, and administrative reform are the three key pillars in the Islamic fight against corruption.

\section{The Linkage Between Corruption and Development: An Islamic Perspective}

In the early Islamic community, equality, accountability, and a high degree of transparency in the early Caliphate saw public funds handled with great caution and care, with military expeditions to prevent corruption.Acceptance of what constitutes corrupt behavior is culture specific and various from country to country. Did pre-Islamic Arab cultural values overtake Islam's universal values? Or did the failure result from the Muslims' inability to actualize their preferred set of norms via rationally designed institutions, lately even for such simple tasks as education in Islamic ethics? The suggestion now is that ethics can empower as well as constrain (ADAM SMITH, 1976).

Ethical norms, and the leading institutions by giving force to them, can widen horizons and choices, enabling individuals to do more than would have been possible in their absence. An Islamic-type approach that relies solely on seeking a moral rebirth from within the individual is seriously deficient. While consciousness-raising is needed, reliance upon self-restraint is not enough. According to some writers, the problem is that mainstream western philosophy does not distinguish between values (in which there is a right" and wrong" and therefore a second-order preference exists) and tastes (in which there is no right" or wrong"). (HENRY B. VEATECH, 1971).

In contrast to the Platonic concept of the good and the Kantian focus onthe ought and its justification, modern analytic philosophy has sought todevelop against thebackdrop of a value-neutral world. Accordingly, internal accountability should be supplemented by external checks and balances. Thus, privatization of public institutions and the application of the familiar cost-benefit approach to the provision of social goods is another safeguard. Also, making use of highly qualified internal and external auditors is essential. The recruitment of government officials should be based upon competence and integrity, and they should be paid adequate wages. The law should be clear enough and justly applied to all. A freely elected legislative body that represents all groups of society should exist and its decisions should be binding on all, including the head of state. Also of centrality is the existence of an independent judiciary system and free press. The educational system is of vital importance to transmit Islamic values. (Yousif, Y. 1980).

\section{Levels of Punishments of Corruption and Bribery in Islamic Penal Law}

Islamic scholars agree that punishment cannot be imposed unless three requirements have been satisfied.

The punishment must:

(1) Be consistent with the principle of legality;

(2) Be individualized; and

(3) Apply equally to all persons.

Thus, in the earliest days of the Islamic state, determining the criminality of acts and prescribing their penalties was left to the ruler, who decided himself or delegated the authority to judges under the system of Ta'azir. (MOHAMED A. ARAFA, 2013)

Contemporary Islamic jurists call for the need to codify all crimes and penalties. For instance, the Kingdom of Saudi Arabia, where Shari'a serves as public law, has specified some Ta'azir crimes and their punishments in its statutes. Egypt, which has a criminal code, also began a project to reform its penal law in accordance with Islamic legal principles, including the legality principle. Observing the three objectives of punishment (justice, general deterrence, and rehabilitation or reformation) under Shari_a, Islamic law retains the traditional penalties of deprivation of liberty and pecuniary sanctions.

In addition to these categories of punishment, there are other penalties which are designed to instill morality. Islamic scholars consider penalty as a deterrent before the act and suppression after it. Thus, knowledge of punishment is intended to prevent the commission of the criminal act, and its execution thereafter should prevent the offender from in engaging in similar conduct in the future.

\section{Volume 5 Issue 5, May 2016}




\section{International Journal of Science and Research (IJSR) \\ ISSN (Online): 2319-7064}

Index Copernicus Value (2013): 6.14 | Impact Factor (2015): 6.391

\section{Conclusion}

Corruption has been largely overlooked within the Muslim communities, this paper primarily objectives of elucidating the Islamic practices position and to examine if Muslim majority countries and communities are actually implementing Islamic practices towards abolition and eradication of corruption in their own States and societies. As the paper discovered, its condemns corruption as a severe threat to the social, economic, and ecological balance and reveals in details the various Islamic dispositions and punishment which are meant to curb the endemic practices of corruption across States and boarders.

However, it is within this framework of divine mercy and justice that a Muslim should belief that God is fully aware of his abilities and limitations, and will not overburden him or subject him to any duress or coercion. Not only does this fill a believer's heart with contentment and peace of mind, but it also inspires him to discharge his duties to the best of his ability. He is fully aware that any weakness he may experience is not because the task is excessive, but due to his own shortcomings, and this, in turn, motivates him to strengthen his resolve and strive for excellence in his actions.

As Islam accept plurality in politics, adopt the party system, practice free and honest elections, build an independent judiciary system, and open the door for freedom of the press and official transparency.

Religious and moral educations of all spheres of our transactions if guided by proper application of religious values, social justice, and linking them with a broader worldview will help crime prevention and serve as both deterrence and rehabilitation by the application of Islamic principles for punishment.

First, the penalty must result in deterring the criminal and punishing him proportionately to his deed.

Second, the punishment must lead to his rehabilitation and deterrence rather than repression, which leads to torture and the violation of human dignity.Last but not least, corruption can be tackled by moral education designed to inculcate in believers a clear second-order preference for virtuous behavior, reinforced by legal structures, and administrative systems reflecting and supporting this stance.

Equally important are the significant ethical and moral dimensions to reducing corruption, if only because there are situations where the external constraints confronting officials are weak and self-restraint is needed. Ethics can be empowering, as well as making good practical sense, since ultimately everyone benefits from the behavioral boundaries that ethics dictate. There is room for isolation of Islamic for combating corruption. This is how Islam molded the Muslim community. When such stories are told, we may think they are legends. But the fact is that there is no legend in all this; it was the plain reality.

\section{References}

[1] L. Macfie, Glasgow ed., 1759 (Oxford: Oxford University Press, 1976).

[2] ABU AL-ABBAS AHMAD IBN JABIR BALADHURRI KITAB FUTUH AL-BULDAN [THE ORIGINS OF THE ISLAMIC STATE] 125-26, 344-45 (Philip Khuri Hitti trans., 1968) Ummar ibn AlKhattab (RA) is the second of the four -rightly guided" Caliphs. Ummar also codified Islamic law, and was known for his simple lifestyle and modest living.

[3] ADAM SMITH, THE THEORY OF MORAL SENTIMENTS, (eds. D. D. Raphael \& Benjamin C.D. Diara, and Nkechinyere G. Onah,(2014) Corruption and Nigeria's Underdevelopment: a Religious Approach, Research on Humanities and Social Sciences, ISSN 2222-1719 (Paper) ISSN 2222-2863 (Online), Vol.4, No.4, 2014

[4] Bukovansky, M. (2006) The hollowness of the anticorruption discourse. Review of International Political Economy, 13(2), pp 181-209.

[5] Chukwuezi, B. (2000) Issues in Community Develoment, Nsukka: Mike Social Press

[6] Giddens, A. (1981) Power, Property and State" in A Contemporary Critique of Historical Materialism, Berkley: University of California Press.

[7] HANS WEHR, THE HANS WEHR DICTIONARY OF MODERN WRITTEN ARABIC (J.N. Cowan,ed., 3rd ed. 1976).

[8] HENRY B. VEATECH, FOR AN ONTOLOGY OF MORALS: A CRITIQUE OF CONTEMPORARY ETHICAL THEORY (1971).

[9] Marquette, H. (2003) Corruption, Politics and Development: The Role of the World Bank, Basingstoke: Palgrave.

[10] Marquette, H. (2007) Civic education for combating corruption: lessons from Hong Kong and the United States for donor-funded programmes in poor countries. Public Administration and Development, 27(3), pp 239 50.

[11]Md. Shahnur Azad Chowdhury*,Md Musa Khan Ms Sultana Akter, EJBM-Special Issue: Islamic Management and Business, ISSN 2222-1719 (Paper) ISSN 2222. Vol.5 No.11 2013

[12] MOHAMED A. ARAFA Adjunct Professor of Islamic Law at Indiana University Robert H. McKinney School of Law; Assistant Professor of Criminal Law and Criminal Justice Systems at the Alexandria University Faculty of Law (Alexandria, Egypt). S.J.D., Indiana University Robert H. McKinney School of Law (2013)

[13] MUHAMMAD AYUB, AN INTRODUCTION TO TAKAFUL-AN ALTERNATIVE TO INSURANCE 1, available at http://www.sbp.org.pk/departments/ibd/Takaful.pdf.

[14] Normal Calder, Legal Thought and Jurisprudence, in 2 THE OXFORD ENCYCLOPEDIA OF THE MODERN ISLAMIC WORLD 450, 456 (John L. Esposito ed., 1995).

[15] Polzer, T. (2001) Corruption: Reconstructing the Bank's Discourse. London: London School of Economics, DESTIN Working Paper No 18. 


\section{International Journal of Science and Research (IJSR) \\ ISSN (Online): 2319-7064}

Index Copernicus Value (2013): 6.14 | Impact Factor (2015): 6.391

[16] World Bank (1997) Helping Countries Combat Corruption: The Role of the World Bank, Washington DC: The World Bank.

[17] Wraith, R. and Simpkins, E. (1963) Corruption in Developing Countries, London: George Allen and Unwin Ltd.

[18] Yousif Khalifa Al-Yousif, Economic Development in the United Arab Emirates: 1975-1990, 8 J. OF ECONOMICS AND ADMINISTRATIVE SCIENCES, 23-78 (1990). See also Yousif Khalifa Al-Yousif, Corruption and Development: An Islamic View (unpublished research paper on file with author). 